\title{
Mineralization Rates of Soil Forms of Nitrogen, Phosphorus, and Potassium as Affected by Organomineral Fertilizer in Sandy Loam
}

\author{
Ayeni Leye Samuel and Adeleye Omotayo Ebenezer \\ Department of Agricultural Science, Adeyemi College of Education, PMB 520, Ondo State, Ondo City, Nigeria \\ Correspondence should be addressed to Ayeni Leye Samuel; leye_sam@yahoo.com
}

Received 29 April 2014; Revised 15 June 2014; Accepted 23 June 2014; Published 15 July 2014

Academic Editor: Othmane Merah

Copyright (C) 2014 A. Leye Samuel and A. Omotayo Ebenezer. This is an open access article distributed under the Creative Commons Attribution License, which permits unrestricted use, distribution, and reproduction in any medium, provided the original work is properly cited.

\begin{abstract}
Farmers tend to use organomineral fertilizers as a result of inadequacies embedded in the sole use of organic and mineral fertilizers. A laboratory incubation study to determine the rate of the forms of $\mathrm{N}, \mathrm{P}$, and $\mathrm{K}$ released by organomineral fertilizer was conducted at Adeyemi College of Education, Ondo, southwest Nigeria, in 2013. Organomineral fertilizer (OMF) at the rates of 0, 0.125, 0.25, 0.5 , and $1.0 \mathrm{~g} / 100 \mathrm{~g}$ soil to represent $0,2.5,5,10$, and $20 \mathrm{t} \mathrm{ha}^{-1} \mathrm{OMF}$, respectively, was incubated for ninety days. The treatments were replicated three times and arranged in a completely randomized design. The determined forms of $\mathrm{N}$ were total $\mathrm{N}, \mathrm{NH}_{4}-$ $\mathrm{N}$, and $\mathrm{NO}_{3}-\mathrm{N}$; the forms of $\mathrm{P}$ were total $\mathrm{P}$, solution $\mathrm{P}$, and available $\mathrm{P}$ while the forms of $\mathrm{K}$ were total $\mathrm{K}$, solution $\mathrm{K}$, and exchangeable $\mathrm{K}$. Organomineral fertilizer significantly increased $\mathrm{N}, \mathrm{NH}_{4}-\mathrm{N}, \mathrm{NO}_{3}-\mathrm{N}$, total $\mathrm{P}$, solution $\mathrm{P}$, exchangeable $\mathrm{P}$, solution $\mathrm{K}$, and exchangeable $\mathrm{K}$ at all rates with different values. The rate of ammonification of $\mathrm{N}$ was higher than the rate of nitrification of $\mathrm{NH}_{4}+\mathrm{N}$ to $\mathrm{NO}_{3}+\mathrm{N}$ especially at 10 and $20 \mathrm{t} \mathrm{ha}^{-1}$ OMF. Application of 5 and $10 \mathrm{t} \mathrm{ha}^{-1}$ OMF could be used to increase soil forms of $\mathrm{N}, \mathrm{P}$, and $\mathrm{K}$.
\end{abstract}

\section{Introduction}

The aim of a farmer is to have bumper harvest and to get it depending on soil productivity. This leads to the philosophy that emphasises the need to apply fertilizers when economic yield is likely to occur. The essential nutrient elements are $\mathrm{N}, \mathrm{P}, \mathrm{K}, \mathrm{Ca}, \mathrm{Mg}$, and S. Among these nutrient elements, N ranks first in plant requirement and phosphorus $(\mathrm{P})$ ranks second followed by potassium (K). N, P, and K are referred to essential nutrients because nearly all plants use them for growth and development. Their deficiencies cannot be corrected by another element and are needed by the plants before they can complete their vegetative and reproductive cycles. Many plants require them throughout their life cycles. The nutrients are expected to be present in the soil in proper form and in proper balance. Their misuse can pose threats to water quality and can also cause nutrient antagonism which may result in low crop yield.
Farmers are in the habit of improving soil fertility through the addition of mineral fertilizers and organic manures, but the sole use of either fertilizer has not solved the problem of nutrient deficiencies. This necessitates research into the use of combined organic and inorganic fertilizers [1]. Organomineral fertilizers are produced by fortifying agro wastes with mineral fertilizer. The interest in organomineral fertilizers arose from the demerits of organic and mineral fertilizers such as high cost, scarcity of inorganic fertilizer, and their deleterious effect on soil physical properties as well as bulkiness and low nutrient content in the case of organic manures [2]. Organomineral fertilizers combine the attributes of mineral and organic manures. They are known to contain considerable amount of N, P, and $\mathrm{K}$ which are the three major nutrient elements needed by crop to complete both vegetative and reproductive cycles [3]. Integrated application of agro wastes and household refuse have been found to increase the productive capacity of soils [4]. 
Forms of $\mathrm{N}$ present in soils include organic $\mathrm{N}, \mathrm{NO}_{3}-\mathrm{N}$, $\mathrm{NH}_{4}-\mathrm{N}, \mathrm{NO}_{2}, \mathrm{~N}_{2} \mathrm{O}, \mathrm{NO}$, and $\mathrm{NH}_{3}$ gas. Apart from $\mathrm{NO}_{3}-$ $\mathrm{N}$ and $\mathrm{NH}_{4}-\mathrm{N}$, other forms of $\mathrm{N}$ such as $\mathrm{N}_{2} \mathrm{O}, \mathrm{NO}$, and $\mathrm{NH}_{3}$ can escape into atmosphere through denitrification and volatilization. Other sources of $\mathrm{N}$ loss from the soil include erosion, crop removal, and leaching. In crop production, attention is focused on $\mathrm{NO}_{3}-\mathrm{N}$ and $\mathrm{NH}_{4}-\mathrm{N}$. This is because plants absorb $\mathrm{N}$ in form of $\mathrm{NO}_{3}-\mathrm{N}$ or $\mathrm{NH}_{4}-\mathrm{N}$. The $\mathrm{N}$ in form of $\mathrm{NO}_{3}-\mathrm{N}$ is very soluble in water and highly mobile and can easily leach into the soil beyond the reach of plant root. Ammonium nitrogen is less subject to losses from soil by leaching and denitrification. Absorption of $\mathrm{NH}_{4}{ }^{+}$by root reduces $\mathrm{Ca}^{2+}, \mathrm{Mg}^{2+}$, and $\mathrm{K}^{+}$uptake while increases absorption of $\mathrm{H}_{2} \mathrm{PO}_{3}{ }^{-}, \mathrm{SO}_{4}{ }^{2-}$, and $\mathrm{Cl}^{-}$[5].

Forms of soil phosphorus are total $\mathrm{P}$, organic soil $\mathrm{P}$, and inorganic $P$. These forms of phosphorus can be found in solid, liquid phase, or in the interface between solid and liquid. Phosphorus is absorbed by plants in form of orthophosphate ions $\left(\mathrm{H}_{2} \mathrm{PO}_{4}{ }^{-}\right.$or $\left.\mathrm{HPO}_{4}{ }^{-}\right)$. Plants absorb $\mathrm{H}_{2} \mathrm{PO}_{4}{ }^{-}$more than $\mathrm{HPO}_{4}{ }^{2-}$. Availability of high $\mathrm{Ca}$ or $\mathrm{Al}$ in the soil may hinder $\mathrm{P}$ uptake by plants. The problem associated with long-term applications of phosphatic fertilizers is the increase of $\mathrm{P}$ levels exceeding crop requirements [6].

Potassium is not commonly deficient in tropical soils as nitrogen and phosphorus. This is because it is adsorbed by the soil particles and this is the reason why it is not easily lost. Potassium is common in most soils, but its availability depends on the amount of exchangeable K present in the soil.

Ayeni [1] found that the integrated soil nutrition management is more feasible in maintaining nutrients status as well as increasing crop production than single application of mineral or organic fertilizers and it advocated the use of combined organic wastes and mineral fertilizers. Understanding the rate by which OMF released plant nutrients to the soil will be a guide to the fertilizer recommendation to avoid its over- or underutilization by farmers. Most arable crops complete their vegetative and reproductive cycles within three months of planting. Thus, predicting the amount of plant available N, P, and $\mathrm{K}$ produced by agrowaste amended soils is necessary for proper plant nutrition and protection of ground and surface water quality [7]. The objective of this study was to determine the effect of organomineral fertilizer on the forms of $\mathrm{N}, \mathrm{P}$, and $\mathrm{K}$ released into Alfisol in southwestern Nigeria within 90 days.

\section{Materials and Methods}

Laboratory incubation study was conducted in sandy loam soil to determine the rate of forms of N, P, and $\mathrm{K}$ released from organomineral fertilizer. Surface soil sample $0-20 \mathrm{~cm}$ was randomly collected and bulked from a farmer's field in Ondo in southwestern Nigeria. The soil samples were transferred to Adeyemi College of Education, Department of Agricultural Science, Laboratory for the incubation study.

The soil sample was air-dried and allowed to pass through $2 \mathrm{~mm}$ sieve. 100 grams of sieved soil sample was weighed into a well-labelled cup according to the treatments. The soil samples used for the experiment were preincubated for one week at $60 \%$ water holding capacity prior to the treatments application. The treatment applied was the OMF produced by the Ondo State Government under the Waste to Wealth Management Programme in Nigeria. The treatments used were $0,0.125,0.25,0.5$, and $1.0 \mathrm{~g} / 100 \mathrm{~g}$ soil to represent 0 , $2.5,5,10$, and $20 \mathrm{tha}^{-1} \mathrm{OMF}$, respectively. Equal volume of distilled water was added to each soil sample weekly for three (3) months. The pots were covered with perforated asbestos to give room for exchange of air. At the end of the 90 days, the incubated soil samples were air-dried and chemically analysed.

The $\mathrm{pH}$ of the soil samples was determined using glass electrode photometer in 1:2 soil-water ratio. Organic matter content of the sample was determined with the use of Walkley-Black wet oxidation method.

Total nitrogen $(\mathrm{N})$ was determined by the normal microkjedahl method. Nitrate nitrogen and ammonium nitrogen were extracted with $1 \mathrm{MKCl}$ solution and determined using steam distillation technique [8]. Ammonium nitrogen and nitrate nitrogen contents were determined with the use of spectrophotometer and flow injection analyzer method, respectively. Organic carbon was determined by Walkley and Black [9] method. Available phosphorus (P) was extracted by Bray-1 method and determined colourimetrically. The Murphy and Riley [10] procedure was also used to determine solution $P$ (i.e., addition of a mixed reagent containing ammonium molybdate, antimony potassium tartrate, ascorbic acid, and sulphuric acid to a neutral). The absorbance of the blue solution was measured at a wavelength of $882 \mathrm{~nm}$. Digestion method was used to extract total P, that is, sulphuric acid-potassium sulphate-copper sulphate digestion procedure, and determined by AAS.

Potassium content was fractionated into water soluble $\mathrm{K}$, exchangeable $\mathrm{K}$, and total $\mathrm{K}$. Water soluble $\mathrm{K}$ was extracted in 1:2 soil-water suspension after shaking for 2 hours with mechanical shaker and allowed to stand for 16 hours according to Mclean [11]. Exchangeable $\mathrm{K}$ was extracted from soil with $1 \mathrm{~N} \mathrm{NH}_{4} \mathrm{OAc}$ buffered at $\mathrm{pH} 7$ while total $\mathrm{K}$ was obtained by digestion according to Pratt method [12]. The K extracts were determined by flame photometer.

Exchangeable bases were extracted with neutral ammonium acetate. Ten (10) grams of soil sample was put into conical flask. $100 \mathrm{~mL}$ of the extracting solution $\left(\mathrm{NH}_{4} \mathrm{O}: \mathrm{Ac}\right)$ was added. It was shaken for an hour, filtered, and made up to $100 \mathrm{~mL}$ with $\mathrm{NH}_{4} \mathrm{OAC}$. Exchangeable bases $\mathrm{Ca}, \mathrm{Mg}$, and $\mathrm{Na}$ were determined from the filtrate by atomic absorption spectrophotometer (AAS).

2.1. Statistical Analysis. Statistical analysis was carried out using ANOVA and LSD was used to separate the mean and presented in form of graph.

\section{Result and Discussion}

According to the manufacturer label, the organomineral fertilizer used for the experiment contained 3.5, 2.5, and $4 \%$ for $\mathrm{N}, \mathrm{P}$, and $\mathrm{K}$, respectively. The total $\mathrm{N}$ of the soil used for the experiment was lower than $0.15 \%$ showing that the soil 


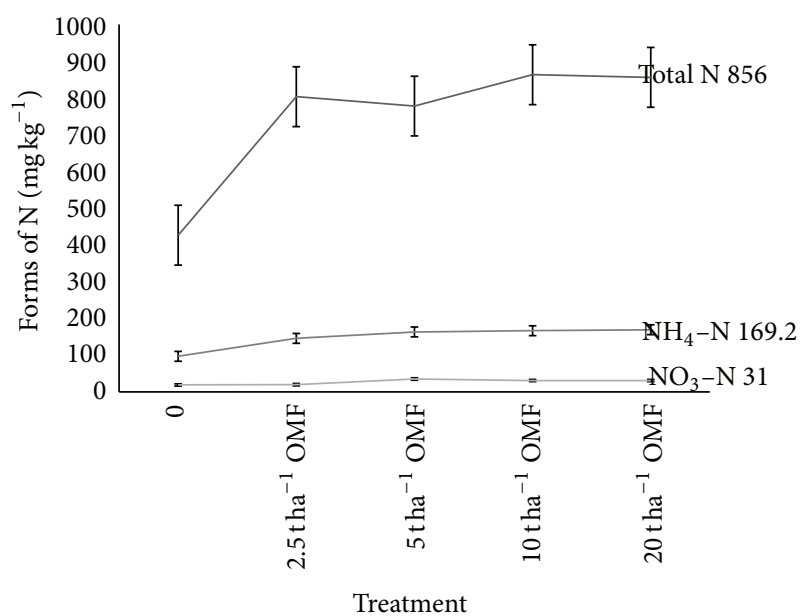

FIgURE 1: Effect of organomineral fertilizer on forms of N. Total N Lsd $(0.05)=11.20, \mathrm{NO}_{3}-\mathrm{N}=4.02$, and $\mathrm{NH}_{4}-\mathrm{N}=5.11$.

was deficient in $\mathrm{N}$ and thereby needed $\mathrm{N}$ fertilization. The soil contained $20 \mathrm{ppm} \mathrm{NNO}_{3}-\mathrm{N}$ (medium), $7.8 \mathrm{ppm}$ available $\mathrm{P}$ (low), $2.14 \mathrm{C} \mathrm{mol} \mathrm{kg}^{-1}$ (medium), and $\mathrm{K} 1.64 \mathrm{C} \mathrm{mol} \mathrm{kg}^{-1}$ according to Sobulo and Osiname [13], Bationo et al. [14], Sanchez et al. [15], Akinrinde and Obigbesan [16], and Agboola and Corey [17]. The soil textural class was sandy loam with $73.6,8.6$, and $17.8 \%$ sand, silt, and clay, respectively.

In Figure 1, total $\mathrm{N}, \mathrm{NO}_{3}-\mathrm{N}$, and $\mathrm{NH}_{4}-\mathrm{N}$ increased as the level of OMF increased indicating that OMF as low as $2.5 \mathrm{tha}^{-1}$ is beneficial as a source of $\mathrm{N}$ to the soil. Addition of organomineral fertilizer was expected to add N, P, and $\mathrm{K}$ to the soil since analysis showed that it contains $\mathrm{N}, \mathrm{P}$, and $\mathrm{K}$. Organomineral fertilizer applied at 10 and $20 \mathrm{tha}^{-1}$ recorded the highest increase in total $\mathrm{N}, \mathrm{NH}_{4}-\mathrm{N}$, and $\mathrm{NO}_{3}-\mathrm{N}$ (Figure 1). Though total $\mathrm{N}$ does not indicate plant available $\mathrm{N}$ and is not the sum of $\mathrm{NH}_{4}-\mathrm{N}$ and $\mathrm{NO}_{3}-\mathrm{N}$, it is a tool for determining the amount of organic $\mathrm{N}$ that can mineralize to inorganic form of $\mathrm{N}$ in future. The amount of total $\mathrm{N}$ present in the soil samples treated with OMF at all rates was significantly high (Figure 1). It was expected that the rate of conversion of $\mathrm{NH}_{4}-\mathrm{N}$ to $\mathrm{NO}_{3}-\mathrm{N}$ should be rapid [18], but the reverse was the case in the soil samples treated with 2.5, 10, and $20 \mathrm{tha}^{-1}$ OMF. The soil conditions might have favoured ammonifying bacteria than the nitrifying bacteria. The higher increase in $\mathrm{NH}_{4}-\mathrm{N}$ than in $\mathrm{NO}_{3}-\mathrm{N}$ recorded in this experiment signified that the rate of ammonification was higher than the rate of nitrification. It was noted that application of 5,10 , and $20 \mathrm{tha}^{-1} \mathrm{OMF}$ raised the level of $\mathrm{NO}_{3}-\mathrm{N}$ to $30 \mathrm{mg}$ that is recommended as the critical level for optimum crop production in southwest Nigeria. It was also noted that the $\mathrm{NH}_{4}{ }^{+}$released by OMF within the period of the incubation was too high compared with $\mathrm{NO}_{3}-\mathrm{N}$ as clearly shown by the percentage increase in $\mathrm{NO}_{3}-\mathrm{N}$ and $\mathrm{NH}_{4}-\mathrm{N}$ (Table 1). The percentage rate of conversion of $\mathrm{NH}_{4}-\mathrm{N}$ to $\mathrm{NO}_{3}-\mathrm{N}$ was the highest in $5 \mathrm{tha}^{-1}$ OMF showing that mineralization rate was the highest in $5 \mathrm{tha}^{-1}$ OMF. The $\mathrm{N}$ present in $5 \mathrm{t} \mathrm{ha}^{-1}$ OMF would be easily released for the immediate crop. The high value of total $\mathrm{N}$ compared with $\mathrm{NH}_{4}-\mathrm{N}$ and $\mathrm{NO}_{3}-\mathrm{N}$ recorded
TABLE 1: Percentage increase in forms of nitrogen.

\begin{tabular}{lccc}
\hline Treatment & Total & $\mathrm{NO}_{3}-\mathrm{N}$ & $\mathrm{NH}_{4}-\mathrm{N}$ \\
\hline 0 & - & - & - \\
$2.5 \mathrm{tha}^{-1} \mathrm{OMF}$ & 50.4 & 5 & 49 \\
$5 \mathrm{t} \mathrm{ha}^{-1} \mathrm{OMF}$ & 92 & 84 & 66 \\
$10 \mathrm{tha}^{-1} \mathrm{OMF}$ & 113 & 63 & 70 \\
$20 \mathrm{tha}^{-1} \mathrm{OMF}$ & 111 & 63 & 74 \\
\hline
\end{tabular}

TABle 2: Percentage increase in forms of phosphorus.

\begin{tabular}{lccc}
\hline Treatment & Total P & Solution P & Available P \\
\hline 0 & - & - & - \\
$2.5 \mathrm{tha}^{-1}$ OMF & 10 & 83 & 87 \\
$5 \mathrm{t} \mathrm{ha}^{-1}$ OMF & 9 & 137 & 137 \\
$10 \mathrm{tha}^{-1}$ OMF & 11 & 191 & 189 \\
$20 \mathrm{tha}^{-1}$ OMF & 17 & 239 & 242 \\
\hline
\end{tabular}

TABLE 3: Percentage increase in forms of potassium.

\begin{tabular}{lccc}
\hline Treatment & Exch. K & Solution K & Total K \\
\hline 0 & - & - & - \\
$2.5 \mathrm{tha}^{-1}$ OMF & -0.06 & 118 & 48 \\
$5 \mathrm{tha}^{-1} \mathrm{OMF}$ & -0.11 & 71 & 120 \\
$10 \mathrm{tha}^{-1} \mathrm{OMF}$ & 6.35 & 82 & 131 \\
$20 \mathrm{tha}^{-1} \mathrm{OMF}$ & 10 & 205 & 186 \\
\hline
\end{tabular}

in all the treatments showed that not all the $\mathrm{N}$ present in soil samples treated with OMF was mineralized during the period of incubation. The remaining $\mathrm{N}$ would likely be useful for crop uptake in the nearest future.

There was no much change in soil $\mathrm{pH}$ when OMF was added to the soil samples. Soil organic matter decreases soil $\mathrm{pH}$ during nitrification as a result of the release of hydrogen ion [19]. Table 4 shows that addition of OMF at all rates significantly increased $(P<0.05)$ soil Ca compared with control which might have obliterated the acidic effect of the mineral fertilizer blended with organic manure. This also might have reduced nitrification. It could also be argued that the presence of high amount of $\mathrm{K}^{+}$might have reduced $\mathrm{NH}^{+}$ fixation. Samuel et al. [5] stated that the presence of $\mathrm{K}^{+}$often restricts $\mathrm{NH}_{4}{ }^{+}$since $\mathrm{K}^{+}$can also fill fixation sites.

Ammonium tolerance limits are narrowed with excessive levels producing toxic reactions. Caution must be exercised in applying large dose of OMF, that is, $20 \mathrm{tha}^{-1}$, to avoid excessive ammonification which may retard crop growth, restricts uptake of $\mathrm{K}^{+}$, and produce symptoms of $\mathrm{K}$ deficiency. Saturating soils with a ready supply of $\mathrm{NO}^{3+}$ can also cause denitrification; that is, conversion of nitrate to various forms of $\mathrm{N}$ can be lost to the atmosphere.

Compared with control, all the treatments significantly $(P<0.05)$ increased soil total $\mathrm{P}$ (Figure 2(a)). Available $\mathrm{P}$ increased as the level of OMF increased. Water P increased as the level of OMF increased up to $10 \mathrm{tha}^{-1}$ and decreased at $20 \mathrm{tha}^{-1}$. Compared with total $\mathrm{P}$, the amount of $\mathrm{P}$ mineralized to solution $\mathrm{P}$ and available $\mathrm{P}$ was low showing that the high 
TABLE 4: Effect of organomineral fertilizer on soil chemical properties.

\begin{tabular}{lcccccccc}
\hline Treatment & $\mathrm{pH}$ & $\mathrm{OC}$ & $\mathrm{Ca}$ & $\mathrm{Mg}$ & $\mathrm{Na}$ & EA & ECEC & $\% B S$ \\
\hline 0 & $6.33^{\mathrm{a}}$ & $1.90^{\mathrm{a}}$ & $3.94^{\mathrm{d}}$ & $1.83^{\mathrm{b}}$ & $1.11^{\mathrm{c}}$ & $1.42^{\mathrm{b}}$ & $8.30^{\mathrm{c}}$ & $82.89^{\mathrm{a}}$ \\
$2.5 \mathrm{t} \mathrm{ha}^{-1}$ OMF & $6.24^{\mathrm{ab}}$ & $1.77^{\mathrm{a}}$ & $4.00^{\mathrm{c}}$ & $0.99^{\mathrm{c}}$ & $1.52^{\mathrm{b}}$ & $1.82^{\mathrm{a}}$ & $8.33^{\mathrm{c}}$ & $78.15^{\mathrm{a}}$ \\
$5 \mathrm{tha}^{-1}$ OMF & $6.15^{\mathrm{b}}$ & $1.73^{\mathrm{a}}$ & $6.01^{\mathrm{b}}$ & $2.55^{\mathrm{a}}$ & $1.48^{\mathrm{b}}$ & $1.64^{\mathrm{ab}}$ & $11.68^{\mathrm{b}}$ & $85.96^{\mathrm{a}}$ \\
$10 \mathrm{t} \mathrm{ha}^{-1}$ OMF & $6.14^{\mathrm{b}}$ & $1.89^{\mathrm{a}}$ & $6.58^{\mathrm{ab}}$ & $2.68^{\mathrm{a}}$ & $1.83^{\mathrm{a}}$ & $1.75^{\mathrm{a}}$ & $12.84^{\mathrm{ab}}$ & $86.37^{\mathrm{a}}$ \\
$20 \mathrm{tha}^{-1}$ OMF & $6.98^{\mathrm{a}}$ & $1.79^{\mathrm{a}}$ & $7.75^{\mathrm{a}}$ & $2.67^{\mathrm{a}}$ & $2.40^{\mathrm{b}}$ & $1.61^{\mathrm{b}}$ & $14.43^{\mathrm{a}}$ & $88.84^{\mathrm{a}}$ \\
\hline
\end{tabular}

Treatments with the same letter are not significantly different at 5\% level using DMRT.

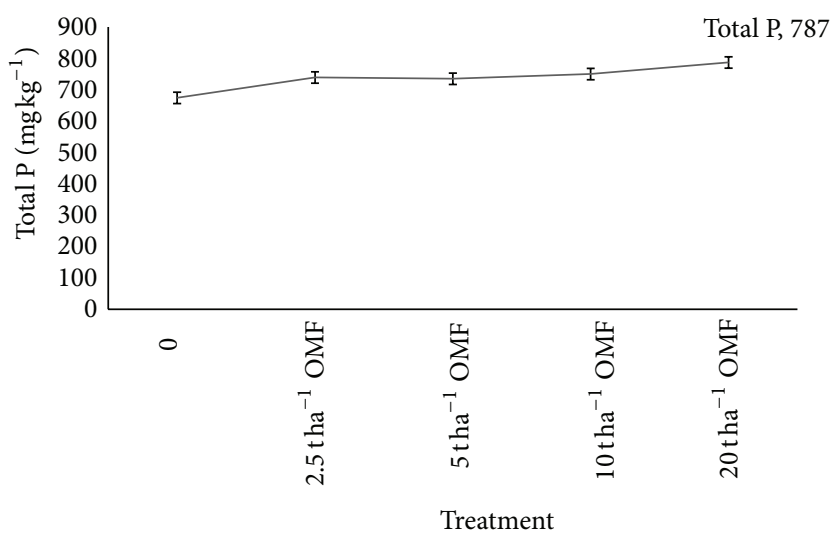

(a)

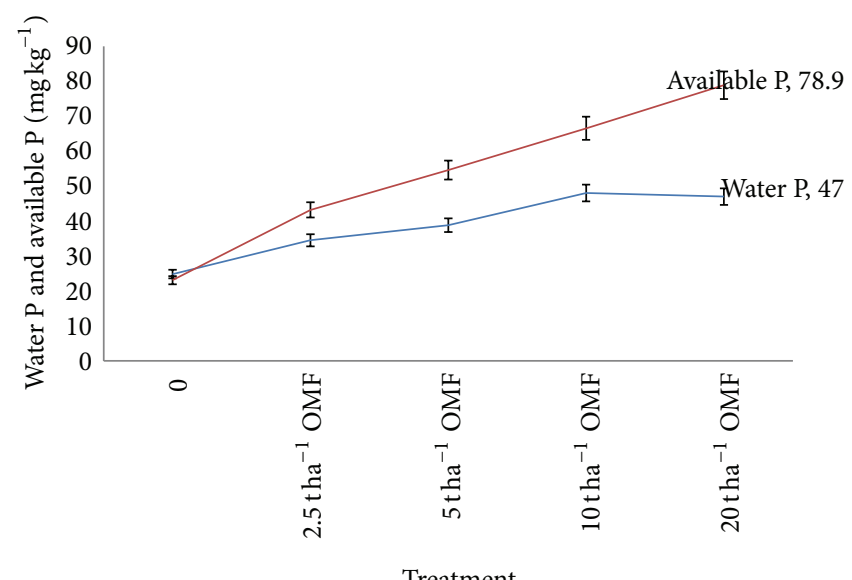

(b)

Figure 2: (a) Effect of organomineral fertilizer on total P. Lsd (0.05) = 11. (b) Effect of organomineral fertilizer on water P and available P. Lsd (0.05) water $\mathrm{P}=6.03$, avail. $\mathrm{P}=8.07$.

amount of $\mathrm{P}$ released to the soil by OMF might have been fixed (Figure 2).

Orthophosphates are readily absorbed by plants. Available $\mathrm{P}$ is the form of $\mathrm{P}$ mostly needed by crop. In this research, application of OMF as low as $2.5 \mathrm{tha}^{-1}$ released more than $30 \mathrm{mg} \mathrm{kg}^{-1}$ that is recommended as the critical level for optimum arable crop production in southwestern Nigeria within 90 days of incubation. The $\mathrm{pH}$ of the soil after the addition of OMF ranged within the level at which $\mathrm{P}$ and $\mathrm{K}$ could be easily mineralized. The favourable soil $\mathrm{pH}$, moisture, and fine texture of the soil were expected to enhance the release of the orthophosphates and $\mathrm{K}$ to the soil. These conditions are favourable for fungi and bacteria that aid in the solubilization of P from inorganic to organic form. This experiment showed that organomineral fertilizer as low as $2.5 \mathrm{tha}^{-1}$ can increase soil available $\mathrm{P}$ to the level that can increase crop production (Table 2). Addition of large dose of OMF to increase soil P might lead to excess $\mathrm{P}$ which could lead to nutrient imbalance especially when the native $\mathrm{P}$ is at medium or high level. Excess $\mathrm{P}$ application is known to move from soil into surface waters and lead to excessive growth of vegetation which can damage aquatic ecosystem [18].

Total $\mathrm{K}$ and available $\mathrm{K}$ increased as the level of OMF increased, but water $\mathrm{K}$ did not follow a definite pattern, though $20 \mathrm{tha}^{-1}$ OMF recorded the highest value (Figure 3).

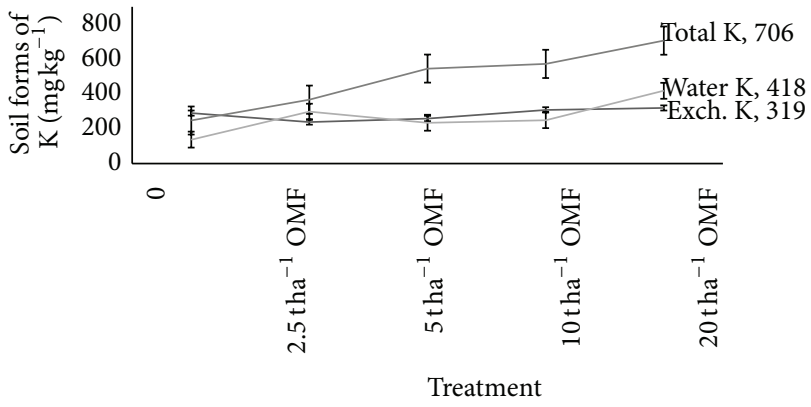

FIGURE 3: Effect of organomineral fertilizer on soil forms of K. Total $\mathrm{K} \operatorname{Lsd}(0.05)=10.05$, water $\mathrm{K}=10.66$, and exch. $\mathrm{K}=12.05$.

Compared with control, application of OMF at all rates significantly increased all forms of $\mathrm{K}$ under study. All the treatments increased the available $\mathrm{K}$ above critical level.

Compared with control, 2.5 and $20 \mathrm{tha}^{-1}$ OMF significantly increased $(P<0.050)$ soil $\mathrm{pH}$ while 5 and $10 \mathrm{tha}^{-1}$ reduced the soil $\mathrm{pH}$ but still favoured $\mathrm{N}, \mathrm{P}$, and $\mathrm{K}$ mineralization (Table 3). This shows inconsistency of organomineral fertilizers on soil $\mathrm{pH}$ which might indirectly affect nutrients mineralization. OMF applied at the highest level recorded the highest $\mathrm{pH}$ among the treatments. This is in line with the assertion of Ojeniyi, [20] that increase in organic manure is 
dependent on the amount of organic manure present in the soil. The $\mathrm{pH}$ favoured the mineralization of $\mathrm{N}, \mathrm{P}$, and $\mathrm{K}$ as recorded in Figures 1, 2, and 3. Researches have shown that some organic manures contain reasonable amount of cations especially $\mathrm{Ca}$ that can reduce soil acidity [21]. There was no significant increase in soil OC and base saturation. Ano and Agwu [22] observed similar decrease in soil organic carbon when an acid soil was incubated with organic materials and attributed the observation to the increase in microbial respiration stimulated by the added manure which might have caused temporary immobilization. Relative to control, all the treatments significantly increased soil $\mathrm{Ca}, \mathrm{Mg}$, and $\mathrm{Na}$ and exchangeable cation capacity (ECEC) (Table 4). Application of 2.5 and $10 \mathrm{tha}^{-1}$ OMF significantly increased exchange acidity compared with control.

\section{Conclusion}

Laboratory incubation study was conducted in sandy loam soil to determine the rate of forms of $\mathrm{N}, \mathrm{P}$, and $\mathrm{K}$ released from organomineral fertilizer. Organomineral fertilizer especially at 2.5, 5, 10, and $20 \mathrm{tha}^{-1}$ increased soil forms of $\mathrm{N}, \mathrm{P}$, and $\mathrm{K}$ to sufficient levels that can boost food production. Further research is needed on the field to substantiate the finding as environmental conditions might have interfered with the incubation study.

\section{Conflict of Interests}

The authors declare that there is no conflict of interests regarding the publication of this paper.

\section{Acknowledgments}

The authors are grateful to Tertiary Education Trust Fund (TETFUND) and the Management of Adeyemi College of Education, Ondo, for providing the fund for conducting this research.

\section{References}

[1] L. S. Ayeni, "Effect of combined cocoa pod ash and NPK fertilizer on soil properties, nutrient uptake and yield of maize (Zea mays)," Journal of American Science, vol. 6, no. 3, pp. 79-84, 2010.

[2] E. A. Makinde, O. K. Oluwa, A. O. Oke, and P. O. Duyile, “ Effects of organic, organomineral and NPK fertilizer treatments on fresh and dry matter yield of Amaranthus cruentus L on soil types in Lagos, Nigeria," New York Science Journal, vol. 3, no. 4, pp. 12-17, 2010.

[3] J. O. Olaniyi and W. B. Akanbi, "Effect of organo mineral and inorganic fertilizers on the yield quality of fluted Pumpkin (Telfaria occidentalis hook.F.)," African Crop Science Conference Proceedings, vol. 8, pp. 347-350, 2007.

[4] P. K. Ghosh, A. K. Tripathi, K. K. Bandyopadhyay, and M. C. Manna, "Assessment of nutrient competition and nutrient requirement in soybean/sorghum intercropping system," European Journal of Agronomy, vol. 31, no. 1, pp. 43-50, 2009.

[5] L. T. Samuel, W. H. Tisdale, D. B. James, and L. H. John, Soil Fertility and Fertilizer, 2003.
[6] P. B. DeLaune, P. A. Moore Jr., and J. L. Lemunyon, "Effect of chemical and microbial amendment on phosphorus runoff from composted poultry litter," Journal of Environmental Quality, vol. 35, no. 4, pp. 1291-1296, 2006.

[7] J. Hirzel, P. Undurraga, and I. Walter, "Nitrogen mineralization and released nutrients in a volcanic soil amended with poultry litter," Chilean Journal of Agricultural Research, vol. 70, no. 1, pp. 113-121, 2010.

[8] J. M. Bremner, "Inorganic forms of nitrogen," in Methods of Soil Analysis. Part 2, C. A. Black et al., Ed., vol. 9 of Agronomy Monograph, pp. 1179-1237, ASA, Madison, Wis, USA, 1965.

[9] A. C. Walkley and T. A. Black, "Estimation of soil organic carbon by chromic acid titration method," Soil Science, vol. 47, pp. 29-38, 1935.

[10] J. Murphy and J. P. Riley, "A modified single solution method for the determination of phosphate in natural waters," Analytica Chimica Acta, vol. 27, pp. 31-36, 1962.

[11] A. J. Mclean, "Potassium supplying power of some Canadian soils," Canadian Journal of Soil Science, vol. 41, pp. 196-206, 1961.

[12] P. F. Pratt, "Potassium," in Methods of Soil Analysis. Agronomy 9 , C. A. Black, Ed., pp. 1022-1030, American Society of Agronomy, 1965.

[13] R. A. Sobulo and A. Osiname, "Soil and fertilizer use in southwestern Nigeria," Research Bulletin 11, IAR\&T, Ibadan, Nigeria, 1981.

[14] A. Bationo, J. Kihara, B. Vanlauwe, B. Waswa, and J. Kimetu, "Soil organic carbon dynamics, functions and management in West African agro-ecosystems," Agricultural Systems, vol. 94, no. 1, pp. 13-25, 2007.

[15] P. A. Pearson Sanchez, K. D. Shepherd, M. J. Soule, F. M. Place, A. U. Mukwunye, and R. J. Bursch, "Soil fertility replenishment in Africa: an investment in natural resource capital," in Replenishing Soil Fertility in Africa, R. J. Bursch, P. A. Sanchez, and F. Calhoon, Eds., pp. 1-46, Soil Science Society of America, Madison, Wis, USA, 1997.

[16] E. A. Akinrinde and G. O. Obigbesan, "Evaluation of the fertility status of selected soils for crop production in five ecological zones of Nigeria," in Proceedings of the 26th Annual Conference of Soil Science Society of Nigeria, pp. 279-288, Ibadan, Nigeria, 2000.

[17] A. A. Agboola and R. B. Corey, "The relationship between soil $\mathrm{pH}$, organic matter, available $\mathrm{P}$, exchangeable $\mathrm{K}, \mathrm{Ca}, \mathrm{Mg}$ and nine elements in the maize tissue," Soil Science, vol. 115, no. 5, pp. 367-375, 1973.

[18] D. Horneck, A. D. M. Sullivan, J. S. Owen, and J. M. Hart, Soil Interpretation Guide, Oregon State University Extension Service, 2011.

[19] R. J. Haynes and M. S. Mokolobate, "Amelioration of Al toxicity and $\mathrm{P}$ deficiency in acid soils by additions of organic residues: a critical review of the phenomenon and the mechanisms involved," Nutrient Cycling in Agroecosystems, vol. 59, no. 1, pp. 47-63, 2001.

[20] S. O. Ojeniyi, "Effect of goat manure on soil nutrient and yield of okra in a rain forest area on Nigeria," Applied Tropical Agriculture, vol. 5, pp. 20-23, 2000.

[21] O. O. Babalola, "Beneficial bacteria of agricultural importance," Biotechnology Letters, vol. 32, no. 11, pp. 1559-1570, 2010.

[22] A. O. Ano and J. A. Agwu, "Effect of animal manure on selected soil chemical properties," Nigerian Journal of Soil Science, vol. 13, pp. 14-19, 2005. 


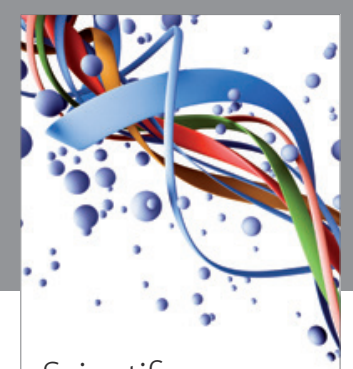

Scientifica
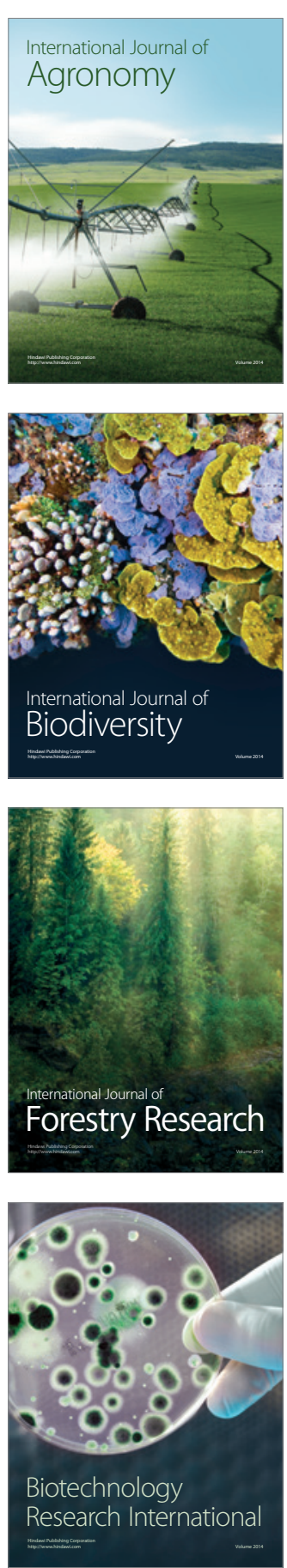
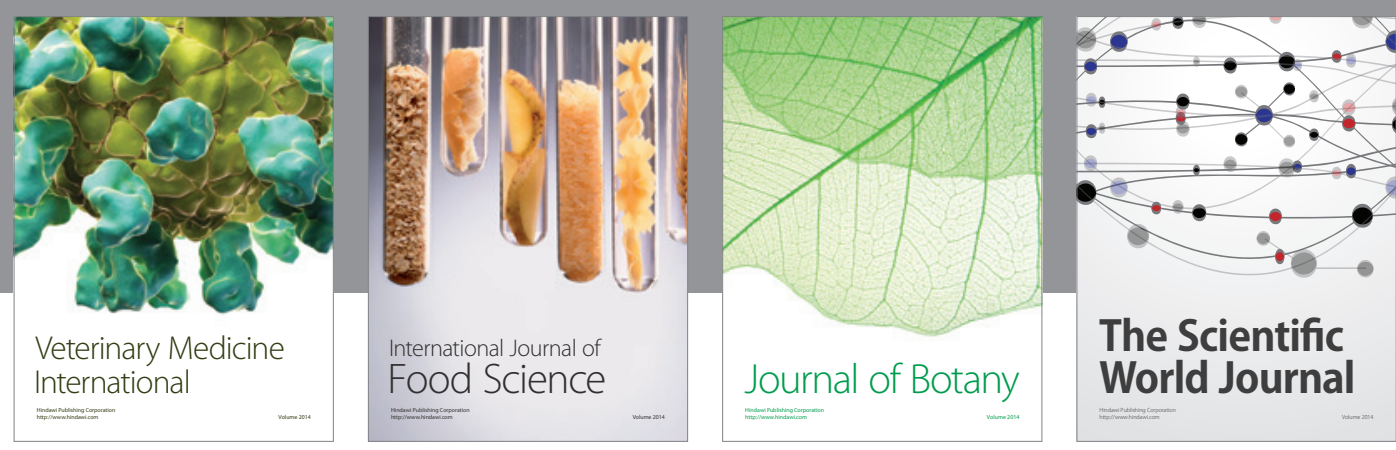

The Scientific World Journal
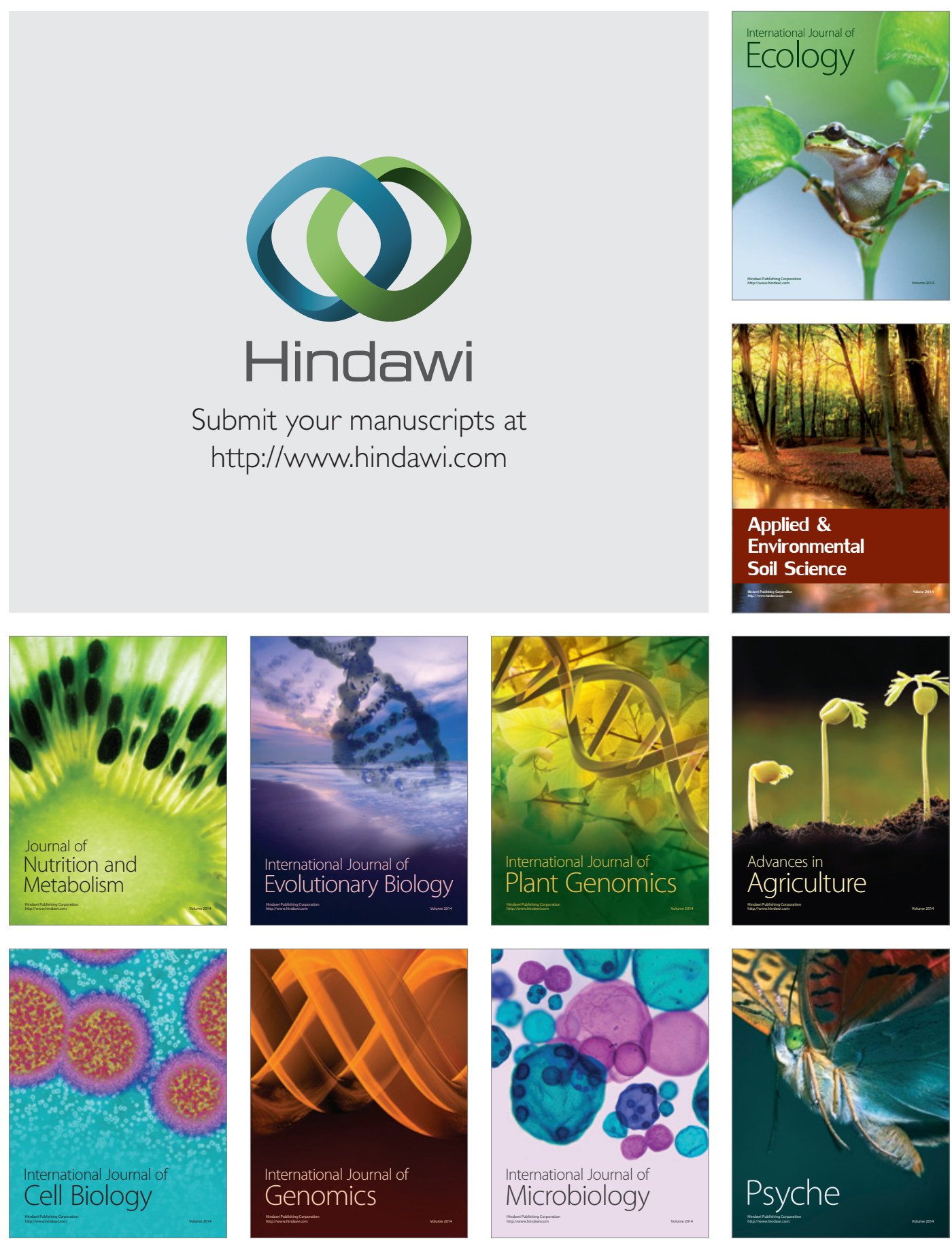